\title{
E3 SUMO-Protein Ligase NSE2
}

National Cancer Institute

\section{Source}

National Cancer Institute. E3 SUMO-Protein Ligase NSE2. NCI Thesaurus. Code C131565.

E3 SUMO-protein ligase NSE2 (247 aa, $\sim 28 \mathrm{kDa}$ ) is encoded by the human NSMCE2 gene. This protein plays a role in DNA double-strand break repair by homologous recombination, the prevention of DNA damage-induced apoptosis, and the sumolyation of protein substrates. 